\title{
Strategy development from triangulated viewpoints for a fast-growing destination toward sustainable tourism development - a case of Phu Quoc islands, Vietnam
}

\author{
Hieu Minh Vu \\ Faculty of Commerce and Business Administration, Van Lang University, Vietnam \\ $\mathrm{Vu}$ Minh Ngo \\ Faculty of Commerce and Business Administration, Van Lang University, Vietnam
}

Received: 28 February 2019. Revision received: 13 May 2019. Accepted: 31 May 2019.

\begin{abstract}
The tourism industry is widely acknowledged as the crucial influencer to the rapid and significant development of the current world and becomes one of the largest and fastest growing economic sectors in the world. Vietnam - a developing country and Phu Quoc island of Kien Giang Province in Vietnam own the great potentials and invaluable resources for tourism development. Nonetheless, Phu Quoc tourism has been also encountering difficulties and facing with several hidden drawbacks by its rapidly fast growth. The general objective of this study is to develop the strategies for tourism development towards sustainable tourism development. The triangulation research method is employed which consists of the secondary and primary data. Secondary data relies on vast sources. Primary data is the results of the surveys by questionnaires with 230 local residents, 150 businesses, and 530 tourists. Furthermore, primary data gains from the semi-structured and in-depth interviews conducted in Phu Quoc with local residents, businesses, tourists, local authorities' officers, and especially with 12 experts. All of the surveyed data was processed with SWOT and IPA analyses. The results of the study will be useful sources for the Phu Quoc tourism development practice and also for teaching as a case study.
\end{abstract}

Key Words: Strategy development, Phu Quoc, Sustainable tourism development, Tourism development, Vietnam.

JEL Classification: M10, Z30, Z32

\section{Introduction}

As one of the largest and fastest growing economic sectors and the third-placed economic contribution in the worldwide (Batta, 2009; UNWTO, 2012; WTTC, 2016), tourism has been chosen as a priority and/or a lifebuoy for their prosperity and economic development (UNWTO, 2012) in many countries and regions. To date, sustainable development becomes popular and has been applied to all industries and sectors in the world and become an avoidable trend in the evolution of human society. Regarding the tourism industry, sustainable tourism or alternative tourism has become part of sustainable development, especially for the destination with high value of natural setting (HigginsDesbiolles, 2009; Zielińska, 2010). 
Vietnam - a developing country does not stay outside the global trend for tourism development especially for its development towards sustainability. Sustainable tourism development has become a special concern in Vietnam. In term of sustainable tourism development, Vietnam government provides great support by launching out many decisions as major institutional frameworks and orientations and the legal foundations like the decision No. 201/QD-TTg dated 22 January 2013 titled "Strategy on Viet Nam's tourism development until 2020, vision to 2030".

Phu Quoc - the largest island in Vietnam located in Kien Giang province owns the great potentials and invaluable resources for economic and tourism development such as tropical forests, marine resource, land resource, beautiful beaches, etc. of which many beaches have been voted by well-known international media and tourism organizations and websites as the most beautiful beaches on the earth. Furthermore, tourism products are bound to find out the various types of historical-cultural relics, cultural heritages, craft villages, gastronomy, etc. Therefore, Phu Quoc has another name of Phu Quoc as "Pearl Island" by its mysterious beauty. The current tourism in Phu Quoc seems to run well and gains successfully and that is the reason for the extension of this economic sector with its benefits as the tourist attraction, employment generation and income increase for the host community. On the other hand, several weaknesses, hidden drawbacks, and risks are revealed in the current situation and for the future development as challenges of transportation, infrastructure, safety and security, accommodation facilities, qualified human resources, unadequate local residents benefit from the tourism, damaging and threatening environment, etc. These issues are currently underestimated and un-corresponded with high exploitation. Furthermore, as a service industry, with the higher demands of the stakeholders, the service quality must be improved. To overcome weaknesses and to strengthen the positive impacts of tourism aiming to be an ideal destination in competition with other destinations in ASEAN region and in the world, tourism development in a more sustainable manner is necessary and essential. The scientific and systematic studies for finding solutions and recommendations to promote the development of tourism in Vietnam are required as an urgent task. Additionally, to date, a holistic study of sustainable tourism development for Phu Quoc does not exist. Therefore, this paper aims to review concepts of sustainable tourism development, the destination management, and strategic management with a focus on SWOT and IPA analyses

to recommend strategies for development of tourism abilities towards a sustainable destination.

\section{Literature review}

\section{1 . The concept of sustainable tourism development}

Sustainable tourism can be regarded as a sustainable development application in the tourism sector (Robinson et al., 2011). With Butler (1993) and Wheeller (1993), the sustainable tourism term has been interpreted in many ways in which all are appropriate or accepted and refers to sustainable tourism development guidelines and management practices that is not a special form of tourism - all types of tourism from the mass to the niche should strive to be more sustainable (UNWTO, 2013). The United Nations World Tourism Organization - UNWTO (2015) points the principle and defines sustainable tourism as 
"tourism that takes full account of its current and future economic, social and environmental imp...acts, addressing the needs of visitors, the industry, the environment, and host communities". Caribbean Sustainable Tourism Policy Framework (2008) states sustainable tourism development as the optimal use of social, natural, cultural and financial resources for national development on an equitable and self-sustaining basis to provide a unique visitor experience and an improved quality of life through partnerships among government, the private sector, and communities. UNWTO (2001) confirms sustainable tourism development is to meet the needs of present tourists and host regions while protecting and enhancing the opportunity for the future. It is envisaged as leading to management of all resources in such a way that economic, social, and aesthetic needs can be fulfilled while maintaining cultural integrity, essential ecological processes, biological diversity, and life support system. In other words, sustainable tourism development is ecologically sustainable, economically viable as well as ethically and socially equitable. It respects the fragile environmental balance that characterizes many tourism destinations, particularly in environmentally sensitive areas on a long-term perspective and this is also considered as the standard model for the studies on sustainable tourism development. As the above mentioned, most of the sustainable tourism and sustainable tourism development literature reflects the triple bottom line of economic, social, cultural and ecological dimensions (Choi \& Sirakaya, 2006; Figge \& Hahn, 2006) and also uses as the standard STD model.

Graph 1. The model of sustainable tourism development

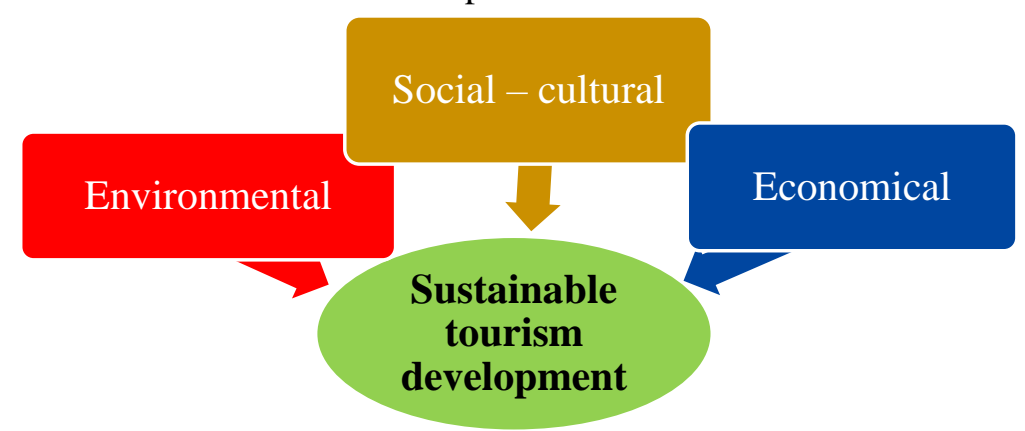

Source: Own (2018) adapted from UNWTO (2005)

With Bauman (2005), tourism is confirmed as a powerful mix of cultural, economic and political phenomena and Hall (1996) and McIntosh et al. (1995) confirm sustainable development is a political concept because to achieve sustainable tourism goals, it depends heavily on the society's political system and power distribution. Choi \& Sirakaya (2006) agree there are two additional dimensions as the political and the technological in sustainable tourism development in their study. Furthermore, Veal (2002) shows the tourism planning and development is a political process whereby decisions are made in order to implement policies and achieve goals. Regarding the political factor in sustainable tourism development, it has been concerned and agreed by many scholars as Pridham (1996), Pforr (2004) and Scheyvens (2011). Farmaki et al. (2015) confirm and agree the three distinct categories of politics and tourism as the public policy and planning analyses, the political economy and development studies, and the study on political stability and tourism. To achieve sustainable tourism development, the informed participation of all relevant stakeholders and the strong political leadership are required to ensure wide participation and consensus building because it is a continuous process, requires constant monitoring of impact and introduces the 
necessary preventive and/or corrective measures whenever necessary (Hens 1998; UNWTO, 2001). In term of the stakeholders, those are the various levels of government (international, national, regional and local tourism organizations), tourism developers and entrepreneurs, tourism industry operators; non-tourism business practitioners and the broader community, including local community groups, indigenous people groups and local residents (Freeman, 1984; Simpson \& Roberts, 2000; Plachciak, 2009). Bramwell \& Lane (2000 cited in Liu, 2010) state sustainable tourism development is a process where the needs of the tourists, the tourist businesses, the host community, and environmental protection are aligned. Additionally, high level of tourist satisfaction should be maintained to ensure a meaningful experience to the tourists and tourists' awareness about sustainability issues should be raised and sustainable tourism practices amongst them should be promoted (UNWTO, 2001).

\section{2 . Destination management in sustainable tourism development context}

Destination management is defined by Mezei (2009) as science of the organization and implementation to tourist destinations through efficient practice of human, financial and material resources and "it is made up of the sum of strategic, organizational, and operational decisions taken to define, promote, and sale the tourist destination product, and by the decisions to influence and drive the flow of tourists to/from a region, respecting the economical requests of the tourist activity participants in that area". According to Franch et al. (2002), destination management is as "the strategic, organizational and operative decisions taken to manage the process of definition, promotion and commercialization of the tourism product and to generate manageable flows of incoming tourists that are balanced, sustainable and sufficient to meet the economic needs of the local actors involved in the destination". Furthermore, UNWTO (2007) states destination management is to serve different needs of tourists and tourism-related businesses as well as the local communities, local businesses, and industries for the maximization of customer value. From all the above definitions, the first thing to be done in the destination management is to create the competitiveness and sustainability for the long-term insurance of the competitiveness because the operation of the tourism owns the interests' competition of many economic, social and political forces which influence policy and management direction beyond traditional organizational boundaries and interdependence among stakeholders (Selin \& Chavez, 1995). In addition, Charters \& Saxon (2007) and Rio \& Nunes (2012) point out a well-managed tourism destination can provide important benefits and a serious impact on ecosystems and the loss of cultural integrity and identity of the destination will exist in case of poor management. Destination management has significant importance in controlling many impacts of tourism, thus insuring its sustainability (Conaghan et. al, 2015). In addition, Jamieson (2006) reveals an evident shift taking place in the standard management of tourism and management concentrates on a more integrated and global philosophy. Also, the management level must be improved to be consistence with sustainable tourism for a destination (Welford \& Ytterhus, 2004). Management of a destination consistent with sustainable tourism has been referred for years such as sustainable tourism destination management (Jamieson \& Noble, 2000), moving destinations towards sustainable tourism (Welford \& Ytterhus, 2004), and sustainable tourism management (Griffin et al., 2012). The most recent terms are sustainable management at destination level (EC, 2013) and sustainable destination management (Dredge \& Jamal, 2013). Notwithstanding, sustainable management 
of destinations requires the cooperation of all performances of businesses, local authority and other organizations and also a holistic and integrated contribution toward the greater goal of the destination (Conaghan et al, 2015), specifically, in destination management, the integration of different planning tools, approaches and concepts are required to shape the management and daily tourism operation in connection with tourism activities (Conaghan et. al, 2015). Furthermore, the destination management is often embodied by a destination management organization - DMO (UNWTO, 2007). DMO refers to a coalition of many organizations and interests working together for mutual goals (Sheehan et al., 2007; UNWTO, 2007; Elbe et al., 2009) and DMO plays significant roles in the sustainable management of tourism destinations. Establishing it correctly is often crucial to success (Jamieson, 2006). On the other hands, the key functions of all destination management in most cases are done by local authorities (UNEP, 2003) because local authorities defined as privileged partners in sustainable tourism development are connectors of the negotiation and mediation among businesses, NGOs, and local communities in tourism destinations (UNEP, 2003) and governments should provide an environment enabling and encouraging all stakeholders to respond to sustainability issues by establishing and implementing tourism development and management policies drawn up in concert with others aiming to local determination and implementation of policies and actions (UNEP \& UNWTO, 2005).

\subsection{Strategic management in the tourism industry}

All the destinations which are influenced by many factors should formulated the development strategies to adapt the changes of the global economy and increase the competitiveness, etc. Regarding the tourism, Yasenok \& Stenyushkina (2016) express strategic management is one of the most effective organizational and economic mechanisms to increase revenues in the region's economy and become one of the main tools to ensure their sustainable development and it is required to apply to all tourist destinations. Tourism development strategies require investments in the tourism infrastructure itself as good road and transportation conditions, safe water accessibility, law and order control, provision of the trained and motivated workforce, other efficient facilities etc. A holistic tourism development strategy must cover all these physical and social infrastructure factors as well as sustainability approaches to businesses (Saner et al., 2015). In the tourism destination, strategic management is an extension of traditional planning methods and the process of strategy formation with the target of sustainable development with the long-term success of tourism organization (Goranczewski \& Puciato, 2010; Jurigová \& Lencsésová, 2015; Mashokhida, et al., 2018). Its main focus is to ensure their economic and social lifespan from the establishment of tourism products which are competitive and contribute to the possibility of income generation from tourism in the long run (Goranczewski \& Puciato, 2010). Strategic management may be carried out at three levels represented by the following strategies (Bednarska et al., 2007 cited in Goranczewski \& Puciato, 2010) as basic, development, leading strategies and formed at the level of a destination as a whole and depends on the specific situation at the time, place and characteristics of the organizations. Therefore, it requires the application of the situational approach. Goranczewski \& Puciato (2010) strategic management goes through with 5 steps as the identification of directions for development; the strategic analysis; the analysis of strategic options; the strategic selection and the strategy implementation and follow-up. 
As known, SWOT analysis is one of the most frequently used methods to build an overall development strategy as well as functional strategies. Gierszewska \& Romanowska (2002 - cited in Goranczewski \& Puciato, 2010) claim "SWOT is not a method of strategic analysis but is a unique algorithm of a strategic analysis process, a systemic proposal and a wide-ranging evaluation of external and internal factors which specify a company's current status and its development potential". In SWOT analysis, the specification of all the factors is not required and prime importance and the future-determined factors should be in focus. The essence of SWOT analysis is to take advantage of strengths and weaknesses, opportunities and threats, and to ensure compatibility between the destination's resources and conditions in its environment. Thereupon, strengths should be used, weaknesses should be eliminated, opportunities should be seized and threats should be neutralized (Gołębiowski, 2001; Strużycki, 2004 cited in Goranczewski \& Puciato, 2010). In addition, to provide useful guidelines in exploration of different attributes of the marketing mix for management action and resources reallocation to achieve competitive advantages, in provision of substantial information for effective marketing and management plans, in promotion of the development of effective marketing programs and strategic decisions, Importance-Performance Analysis (IPA) has been used (Martilla \& James, 1977; Chu \& Choi, 2000; Weber, 2000; Oh, 2001; Matzler et al., 2004; Sever, 2015). IPA is proved as a useful tool in examining customer satisfaction and management strategies in many settings (Matzler et al., 2004; Kitcharoen, 2004; Abalo et al., 2007; Silva \& Fernandes, 2010; Sever, 2015). Especially, in tourism studies, IPA is as a popular management tool (Oh, 2001; Fuchs \& Weiermair, 2003; Janes \& Wisnom, 2003; Wade \& Eagles, 2003; Zhang \& Chow, 2004; Aksu et al., 2010; Ziegler et al., 2012; Chen, 2013; Medina-Muñoz \& Medina-Muñoz, 2014; Lai \& Hitchcock, 2015) because it helps stakeholders investigate the underlying deficiencies, establish priorities in tourism development and improve tourist satisfaction and destination competitiveness (Sever, 2015). However, separately- observed satisfaction and importance values are ineffective to evaluate the success of a tourism destination in meeting tourists' needs. Luck (2011) has done an empirical study to evaluate satisfaction upon on the function of two components of the importance of products or services and their performance because satisfaction involves meeting the expectation of customers, the perception of the quality and therefore, the performance of service attributes can affect the level of satisfaction (Otto \& Ritchie, 1995). Nonetheless, satisfaction scores may gain a higher rating in comparison with the corresponding importance scores, meaning that, tourists are in fact satisfied with the features (Ziegler et al., 2012). IPA is the appropriate approach in examining this comparison and measuring "importance" and "satisfaction". IPA employs a simple graphical approach to compare the mean score for 'perceived importance' of various attributes with the corresponding 'satisfaction rating' using a two-dimensional grid which is classified into four categories of "concentrate here", "keep up the good work", "low priority" and "possible overkill" as in the below figure 
Graph 2. Matrix of Important - Performance Analysis (IPA)

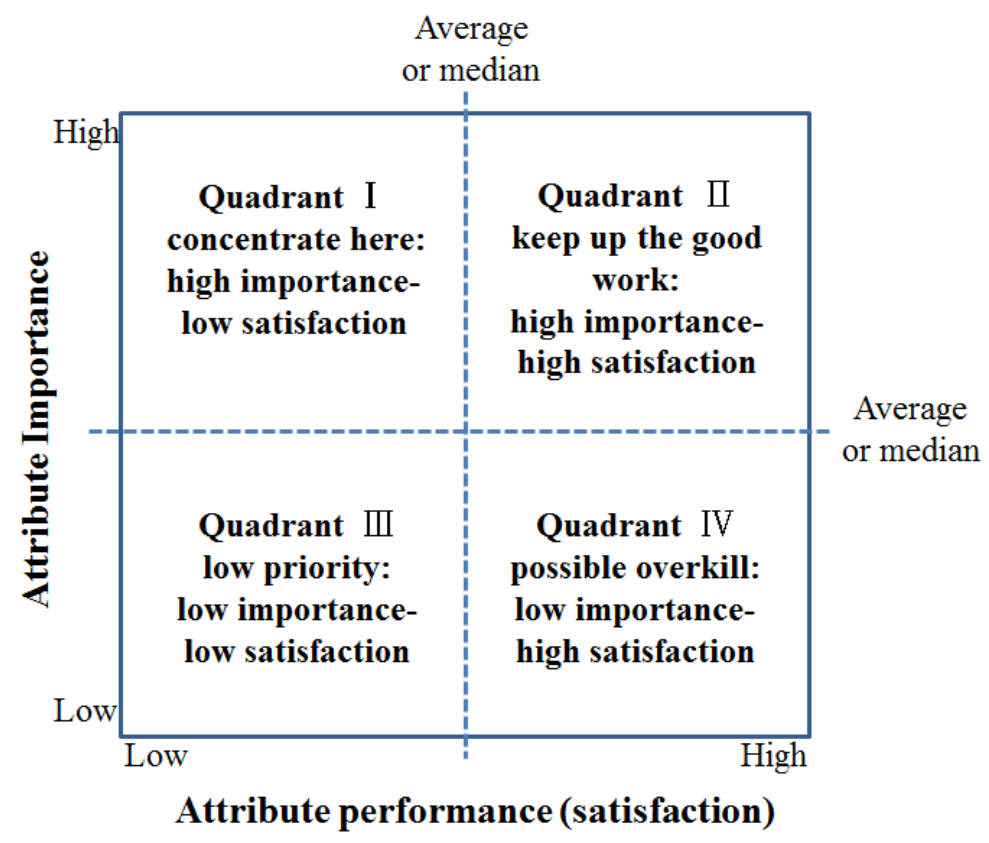

Source: Matzler et al. (2004)

Quadrant 1: "Concentrate Here". This quadrant includes the factors that are considered important by tourists. But the reality of these factors does not meet tourists' expectations (obtained level of satisfaction is low). The factors should be improved.

Quadrant 2: "Keep up the Good Work". This quadrant includes the factors who are considered important by tourists and considered to be accordance with that is felt so that relatively higher level of satisfaction.

Quadrant 3: "Low Priority". The factors included is considered less importance. Increased the variables included can reconsidered because of its influence on the benefits perceived by customers very smaller.

Quadrant 4: "Possible Overkill". The factors are considered less important by tourists. The variables included in this quadrant can be reduced to save costs.

\section{Methodology}

To reach the aim of the study, methodological triangulation is applied with the secondary and primary data through methods of document review, interviews, expert consultation, direct observation, and questionnaire surveys are used in a triangulated manner. Regarding the data analysis, the statistical technique is used. Data were analysed by using descriptive statistics and the procedures are conducted in SPSS 22.0 software.

\section{1 . Research setting}

Phu Quoc island has been regarded as one of the best tourism destinations in Vietnam and has received the attention from foreign tourists in recent years. Most of the beaches in 
Phu Quoc island are of high quality, typically Bai Khem beach, Bai Sao beach, Bai Thom beach, Rach Tram beach, Vung Bau beach, etc. Some of them have been ranked as one of the best secret beaches on earth ranked by the travel and leisure website and top 100 beaches of the world by CNN or by polls of ABC news of Australia Australia's ABC News in 2008 as the world's top five "hidden beaches" or most beautiful and cleanest beaches. Therefore, with those potentials, Phu Quoc can develop tourism types as marine tourism, a high-quality ecotourism area to attract high-class tourists from key international tourist markets.

In 2018, Vietnamese government has defined Phu Quoc as one of the future special economic zones (SEZ) which will receive many advantages and favourable policies for economic development, especially for the tourism industry (Decrees No. 663/QĐ-TT issued by the Prime Minister in 2017). International hotel cooperation has been considering Phu Quoc island as one of the huge potential tourism destination and large-scale tourism projects has been invested in Phu Quoc. In 2018, Phu Quoc for the first time are chosen to be one of the destinations from two international cruise ships from Italy and Germany.

In 2017, Phu Quoc island was visited by 2.963.395 tourists in which there were 318.543 foreign tourists growing 19,1\% comparing with previous year. The economic returns were measured at about 4000 billion VDN (approximately 17 billion USD) growing at $26.7 \%$ rate (Kien Giang statistical office, 2018). In 2018, Phu Quoc island welcomed 4.041.001 tourists in which there were 536.458 foreigners with the growth rate of $36 \%$ comparing with 2017 (Kien Giang statistical office, 2019). The rapid growing in tourism industry in Phu Quoc island is expected to continue in the near future. However, for long-term development, sustainable issue is crucial.

\section{2 . Measurements}

The secondary data was collected from several different sources including Department of Tourism, statistical departments, annual reports of all-level government authorities, state-run corporates, information of officially- registered newspapers and media corporations in Vietnam and in the world, etc. The primary data was gained from the questionnaire survey and semi-structured interviews conducting with three groups: local residents, tourism businesses, and tourists in Phu Quoc island.

As for the questionnaires, it is encompassed 3 different sets of questionnaires for three different groups of local residents, tourism businesses and tourists. The first questionnaire which is designed for surveying local residents consists of 21 items. The second questionnaire includes 20 items and is designed for tourism businesses which supply tourismrelated products in Phu Quoc island such as hotel-accommodations, Gastronomy, Entertainments and Travel services. Lastly, the third one consists of 23 questions aiming for surveying the tourists who are both domestic and foreign one. Three set of questionnaires are dominantly 5-points Likert questions and number of demographic-related questions on each group of respondents. The main topics in there questionnaires focus on the understanding of local residents, business and tourists on sustainable tourism issues, the effects of current tourism policies and activities on local residents' aspects of life, business and tourists 'satisfaction with tourism services, and finally the assessment of local residents on sustainable tourism incentives in Phu Quoc island. The items in three questionnaires are adapted from previous literatures on the related topics (Mau, 2011; Ha, 2013; Tuy, 2014; 
Huong, 2017). In order to validate the data collection techniques, and check comprehensibility and deliver feedbacks to improve the clarity of the questionnaire, pilot tests have been taken place with the related objects before conducting in the broad scale. In total, the questionnaires were tested as the pilot with 4 officers in local authorities, 10 tourists including 5 domestic and 5 foreign tourists, 10 with residents and 6 with entrepreneurs/managers from 2 of hotel businesses, 2 of food catering services, and 2 of craft villages.

After the survey using questionnaires, the data collected are analysis using statistical methods for answering research questions. Then emerging themes which surfaced from the questionnaire are then addressed using indept interviews method and field observation technique.

\section{3 . Data collection and sampling}

For achieving research goals, data collection is conducted using stratified random sampling techniques. The stratified sampling technique is used for preserving the demographic characteristics of Phu Quoc island's key stakeholders as a unique case. This reduces partially the bias which can happen within the data collection processes which can affect to the data analysis results. For surveying using questionnaires, paper-and-pencil method is used first with the support of administrators who can explain unclear questions and ideas in the questionnaires directly to tourists, local residents and managers in tourism business. Then, for improving the sample size, phone call and email media are used to reach more potential respondents based on the data bases drawing from the Phu Quoc tourismrelated government agencies. The data collection process was conducted from January 2018 to May 2018. In general, the sample consists of 150 questionnaires for enterprises, 230 for the local residents, and 530 for the tourists and achieves the respond rate of $34.5 \%$.

Regarding the local resident survey, as to achieve the long-term success of a destination, it is required to gain the local resident acceptance (Ritchie, 1988; Dola \&Mijan, 2006). Local residents are seen as one of the key stakeholders (UNWTO, 2005). Besides, understanding perceptions, attitudes, satisfaction, awareness, and comments toward social, economic and environmental impacts of tourism and their participation in the decisionmaking process of tourism development (Dola \&Mijan, 2006). As a fast-growing destination, the immigration wave exists in Phu Quoc, therefore, local residents are defined as those persons living in the community for at least 4 years, are suitable for the study because they understand enough the tourism in Phu Quoc. As the result, there are 230 residents responding to the questionnaire in which $56.4 \%$ of respondents have lived in Phu Quoc for 10 years or more, $23.91 \%$ of respondents have lived in Phu Quoc for 9-10 years, 13.91\% of respondents have live for 6-8 years and 5.65\% have been in Phu Quoc for 4-5 years. The sample of residents are intentionally made up proportional to the populations of each regions in Phu Quoc island. In general, more than $60 \%$ of residents in the sample are male and $40 \%$ are female which is similar to the demographic characteristics of Phu Quoc island. Most of the residents is not highly educated (only $30 \%$ of respondents were graduated from high school or university) and mainly participate in fishing and agricultural activities (54\%) and tourismrelated activities (35\%) for occupations.

As for the tourists survey, this is to determine their perception and awareness on sustainable tourism, their trip experiences, main activity pattern, opinions and their 
assessment with Phu Quoc as well as their willingness to pay for environmental fee and their desire for further expansion, etc. and to seek the feedback of tourists about the destination. Also, tourists are also encouraged to state out their opinions, their experience of the destination, their satisfaction about their trips which can reflect well the reality of the current situation in the region, their willingness of environmental payment. The total of the survey responses is 530 responses to be analysed in which 320 were domestic tourists and 210 were international tourists mainly from Europe and North America accounted for $64.28 \%$ and Korea (18.09\%), and ASEAN countries. For the domestic tourists, the majority are from the southern and northern provinces. With northern tourists, they are from Hanoi, Thai Nguyen, Nam Dinh, Yen Bai, Hai Duong and Vinh Phuc, etc. (20.94\%) and with the southern part, they are from Ho Chi Minh City, the Mekong Delta, some provinces in central highlands $(53.13 \%)$.

In the business survey, 150 businesses including fishery stakeholders, craft stakeholders, car rentals, restaurants/bars, and tourist shops are represented as the samples. This is conducted to understand their respective commercial and administration concerns, problems faced and perception of the role of the tourist caterers and operators, perception and awareness on sustainable tourism, opinions and their assessment with Phu Quoc tourism resources, satisfaction of respondents with the actions of the public sector for tourism development, their desire for further development and the future strategies and measures for promotion and development to be undertaken by the public sector. The proportions of business respondents taking part in the survey include: Hotel - accommodation at 27.33\%, $18.67 \%$ for travel services, $43.33 \%$ for gastronomy/foodstuff; $4.67 \%$ for entertainment providers and $6 \%$ for others. As for the capital size, $22 \%$ of them have capital of less than VND 500 million; The capital ranges from VND 500 million to VND 1 billion, from VND 1 billion to VND 5 billion, from VND 5 to VND 10 billion accounts for $30 \%, 28 \%$, and $13.33 \%$ respectively. $6.67 \%$ is for the businesses owning its capital of over VND 10 billion (around USD 450,000).

For the later stage of the research, number of in-depth interviews were conducted. In total, there are 12 experts who are stakeholders of the tourism development of Phu Quoc are interviewed to gain the deep exploration of the generality of the tourism industry, the hidden issues of sustainable tourism development in Phu Quoc which are not stated or asked in the questionnaires, the current practice of local community involvement and tourism management. Each interview is based on the semi-structured open questions about the issued emerged from the analysis of the survey. The authors directly interview experts within 90 to 120 minutes. There are 4 experts who are working in Phu Quoc government agencies related to tourism activities, 4 experts who are from university in Kien Giang province and has been working on tourism related research project, 4 experts who are mangers of tourist company which operating mainly in Phu Quoc island. Furthermore, the field observation has been done by several long trips to Phu Quoc, nearly 4 months stay has been done in different areas in Phu Quoc to have a full observation to gain as much as possible from the information (formal or informal) about of local community involvement, tourism development, and management, to study more about issues and problems that may complement the shortages of information afterwards, to identify their previous experience, to learn how the locals behave when they serve in tourism, guest's behaviours and their activities, the tourism support and management of local authorities and the real service quality and activities of the tourism businesses. 


\section{Results and discussion}

\section{1 . The descriptive results of perceptions on sustainable tourism issues}

\subsubsection{The current situation of tourism in Phu Quoc}

Phu Quoc island district of Kien Giang Province is the biggest island in Vietnam in the Gulf of Thailand. The total area is of $589.23 \mathrm{~km}^{2}$. Phu Quoc has a very strategic position in national security and defence in Vietnam. 70 percent of the island is covered with forests. Due to its location in the full tropical climate zone with much of sunny days in the year, the average temperature is from $20^{\circ} \mathrm{C}$ to $25^{\circ} \mathrm{C}$ with less natural calamity and floods and Phu Quoc gains relatively stable geological foundations, rich vegetation and high forest coverage of $64.15 \%$. By the distance, this island is located on the important sea route in Vietnam connecting with many connects with international major tourist centres such as Ho Chi Minh City, Phnom Penh (Cambodia), Kuala Lumpur (Malaysia), Jakarta (Indonesia), Bangkok (Thailand), etc. Also, as a pristine island, Phu Quoc is still not affected by the negative effects of urbanization. This is a very important advantage for the development toward sustainable tourism. In Phu Quoc, there is a national park with an area of nearly 32,000 hectares, accounting for nearly 50 percent of the total area of the island with a very rich ecosystem like a primitive forest (7,000 hectares); mangrove forest (17.9 hectares), etc. (WAR, 2006; Hoan, 2015). Additionally, Phu Quoc owns a long coastline with many beautiful beaches creating excellent tourism beaches which have been ranked as one of the best secret beaches on earth ranked by the travel and leisure website and top 100 beaches of the world. With its existing natural resources and conditions, Phu Quoc also owns traditional craft villages and as a place for many religions. In addition, Phu Quoc possesses many special events, traditional festivals, and historical relics.

In 2017, the tourists reached to 1,959,905 tourists, an increase of $817.44 \%$ compared to the year 2010. Tourism revenue reached VND 8,036 billion, up 46.8\% over the same period. As of February 2018, it increased to 464 accommodations with 12,500 rooms (Phu Quoc department of statistic, 2017). As statistical in 2017, the tourism labor force of Phu Quoc has a relatively low level of education (68.82 percent of the employees who are without any training courses. The tourist management reaches high achievement by the number of tourists to Phu Quoc continuous increase at the average growth rate of 87.77\%. However, the number of international tourists increase at a very limited proportion of $15 \%$ of the total tourists. Furthermore, the average length of stay of tourists is 2.62 days per trip. With a significant increase in tourists, in term of the tourism-related businesses, there is an increased rate in 2010 - 2017 at $616 \%$. Also, the number of accommodations gain a remarkable increase of $170 \%$ with the average occupancy level of around $46.3 \%$. In contrast with the rapid increase of tourism businesses, Phu Quoc is facing with the incompetent human resources, the shortage of the management team of tourism businesses to meet the high demands of the market.

Regarding the total revenue of Phu Quoc's tourism, in the period 2010-2017, the average annual increase rate is $48.65 \%$. On the other hand, 18, 69.43\% of tourists comment about the local safety and security of Phu Quoc from the good to excellent rate. As for the environment, Phu Quoc is facing with the destroying natural resources, harmful living 
environment, increasing waste and contamination. In the dry season, the shortage of water used for residents and saltwater intrusion also occur to the island. Currently, Phu Quoc has about 300 ton of waste/garbage per day, however, only about 150 tons (50\%) of those waste can be collected and proceeded. To assist the tourism marketing and promotion, many governmental policies and decisions have been promulgated to encourage and promote all economic sectors to participate in tourism development in different forms, however, these activities are impermanent and contemporary. To date, Phu Quoc tourism does not have an official logo and slogan, especially with a specific strategy. Phu Quoc tourism Marketing is vague and unimpressed with tourists.

\subsubsection{The result of the business survey}

$84 \%$ of businesses employ the local residents in their businesses which means tourism contribute greatly to the socio-culture of Phu Quoc by significant employment generation to the host community. Also, $71.33 \%$ of surveyed businesses also participate in other local activities such as charity programs, beach cleaning program, etc. Almost all businesses have policies on environmental protection such as water usage and saving, waste management, power saving, etc. However, in the sessions like travel services and foodstuffs, these policies are implemented at a certain/limited level and considered as the notices to employees. however, in four or five-star hotels, the environmental protection policies are strictly implemented. In the other hands, $93.33 \%$ of the businesses are willing to participate or join the programs to make Phu Quoc sustainable. In term of the support from related governmental authorities to adapt and/or access to the resource for tourism development, the local residents and businesses have sometimes missed business opportunities and traditional festivals, craft villages and social safety and security are not evaluated highly.

\subsubsection{The result of local resident survey}

With the rapid tourism increase, $38.26 \%$ of the respondents do not agree and $61.74 \%$ agree that their main incomes are from the tourism but they agree the tourism makes economic issues of the island change most. Regarding the awareness and understanding of sustainable development and sustainable tourism development, the result shows $78.7 \%$ of respondents are not at all familiar or slightly familiar or somewhat familiar with the term "sustainable development; $74.35 \%$ of respondents are not at all familiar or slightly familiar or somewhat familiar with the term "sustainable tourism", $74.35 \%$ of respondents are not at all familiar or slightly familiar or somewhat familiar with the term "sustainable tourism development". Therefore, $73.48 \%$ disagreed and $26.52 \%$ agreed that the term "sustainability" is realistic/practical in a real world situation. In the meantime, the survey result shows $95.65 \%$ of respondents of which includes $44.35 \%$ for never, $32.61 \%$ for rarely, $18.7 \%$ for sometimes have not been asked on local tourism development plans or projects by any related authorities and only $4.35 \%$ have been asked for that.

Additionally, in term of the support to the local residents from related government authorities to tourism development activities, $84.35 \%$ of the respondents reflect that they have not got any supports. As a consequence, $53.48 \%$ dissatisfied and $46.52 \%$ agreed on the implementation of the policies or tourism projects (such as land acquisition policy, 
compensation, site-clearance, and support to employment change, etc.). However, they also state that they agree tourism make Phu Quoc be better, 34.78\% of respondents have completely dissatisfied or dissatisfied and $65.22 \%$ of them express they have levels from satisfy to completely satisfy. In general, regarding tourism activities in Phu Quoc meeting the local residents' expectation or making them satisfy, the result shows $14.78 \%$ of respondents are completely dissatisfy and dissatisfy of which comprise of $9.13 \%$ for completely dissatisfy and $5.65 \%$ for dissatisfy. On the other hand, there are $40 \%$ of them for satisfy, $22.17 \%$ for rather satisfy and $23.04 \%$ for completely satisfy.

\subsubsection{The result of tourist survey}

Relating to the source of information about destination Phu Quoc, the survey result point out many tourists know Phu Quoc from their friends/colleagues/relatives accounted for $35.57 \%$. The next source is from the Internet (27.37\%) and travel agency (16.42\%). However, the survey result shows that $46.2 \%$ of the tourists as the first time tourists, $36.4 \%$ for the second times, $10.6 \%$ for the 3 to 4 times and $4.3 \%$ for from 6 and more. In addition, the Phu Quoc returnable tourists are mostly international tourists, especially for those who are working or have a business trip in/to Vietnam. As for the tourists' purposes, most tourists traveling to Phu Quoc often combine many purposes together. However, for the beach bathe/enjoyment and relaxing are selected at the highest and the most because the beaches of Phu Quoc are selected as one of the ten (10) most beautiful beaches of the world. 84.52 percent of domestic respondents present they travel to Phu Quoc just for visit as well as for food/specialty enjoyment, entertainment, and shopping activities with the ratio of $54.52 \%$; $46.77 \%$ and $42.58 \%$ respectively.

Regarding the stay length of tourists, survey result show tourists stay from 1 to 3 days accounted for a high rate of 38.11\%; 34.34\% for the 4 to 5 days, 20.94\% for 6 to 7 days and from 8 days or more accounted for very low (about 6.6\%). 79.06 percent of domestic tourists state their stays in Phu Quoc from 1 to 3 days and the international tourists stay longer of 4 to 7 days. In term of the spending of the whole trip, 34.91 percent of them spend USD 300 below USD 400, 26.98\% are for spending from USD 100 - below USD 200 (26.98\%) and $26.04 \%$ for the spending from USD 200 - below USD 300. The tourists who spend from VND 10 million (USD 400) or more account for $9.25 \%$ and the tourists with the spending of below USD 100 account for $2.83 \%$. In the aspect of the tourist satisfaction, 60.94 percent of tourists do not feel satisfied with Phu Quoc. Therefore, 60.32\% of tourists do not want or have not determined whether they will return to Phu Quoc and $39.68 \%$ of tourists will return to Phu Quoc. This suggests that the correlation between the tourist satisfaction and their loyalties is relatively low.

\section{2 . The SWOT analysis}

Table 2. The results of SWOT analysis

\begin{tabular}{|l|ll|}
\hline \multicolumn{1}{|c|}{ Strengths } & \multicolumn{1}{|c|}{ Weaknesses } \\
\hline $\begin{array}{l}\text { 1. Favorable and strategic location for } \\
\text { national defense and security }\end{array}$ & $1 . \begin{array}{l}\text { Limited tourists activities in the low } \\
\text { season }\end{array}$ \\
\hline
\end{tabular}


2. Rich and diverse tourism resources with the potentials for local tourism development

3. Favourable and supportive climate

4. Special craft villages with unique and famous products

5. Abundant local labour force

6. Active-supported related government authorities with stable politics and

7. Businesses with knowledge of the locality characteristics

8. Existing master plan for tourism development

9. Right awareness of related stakeholders in sustainable tourism development special incentive policy on investment

2. Poor introduction to local history and culture

3. Poor infrastructure and transportation; unadaptable with development needs

4. Weak labour force quality in total and limited human resources in the tourism sector

5. Poor tourist information system

6. Blur local Marketing

7. Most local businesses as SMEs or very small enterprises

8. Craft villages facing the falling risks from limited investments.

9. Poor linkage and collaboration among stakeholders

10. Un-available general information channel for tourism promotion and its investment

11. Damaged environment and ecology by local tourism and business production

12. Harmful and degraded tourism resources'

13. Slow and limited awareness of local resident on environmental protection and on sustainable tourism development.

14. Inhomogeneous tourism development in Phu Quoc areas

15. Institutional deficiencies and limited state management on sustainable tourism development

16. Complicated and risky local safety and security

17. Limited international tourists

\begin{tabular}{|c|c|}
\hline Opportunities \\
\hline 1. Increasing tendency towards \\
ecotourism, cultural tourism, leisure \\
travel and others by tourists
\end{tabular}

2. Increasing many investors in Phu Quoc

3. Favorable cooperation opportunities in tourism development by strong and deep globalization and international integration

4. Ability to apply new technology in tourism management and development

Threats

1. The low recovered economy in the world leadings the limited tourism needs.

2. Well-established and developed tourism activities of other surrounding islands

3. Strongly increased FDI to Phu Quoc

4. Fierce competition in tourism in the region and in the world which requires high quality requests from tourists

5. The higher practical requirement in tourism in the region and the world. 
5. Gaining foundations for development and related investors' believes from achievements for past years in tourism
6. Adverse climate by seasons or by the climate change which limits the tourists and its increase

Source: Own (2018)

\section{3 . Result of Importance - Performance analysis}

Table 2. Attributes and Coding for Importance - Performance Analysis

\begin{tabular}{|c|l|c|c|c|}
\hline Indexes & \multicolumn{1}{|c|}{ Attributes } & $\begin{array}{c}\text { Satisfaction } \\
\text { (Mean) }\end{array}$ & $\begin{array}{c}\text { Importance } \\
\text { (Mean) }\end{array}$ & $\begin{array}{c}\text { Mean } \\
\text { difference }\end{array}$ \\
\hline & Quadrant 1: High importance - Low satisfaction & & & \\
\hline I2 & Reasonable price & 2,328 & 3,68 & 1,352 \\
\hline I7 & Quality of accommodation & 2,719 & 3,39 & 0,671 \\
\hline & Quadrant 2: High importance - High satisfaction & & & \\
\hline I11 & Air and environment conditions & 2,947 & 3,84 & 0,893 \\
\hline I13 & Natural sightseeing/ landscapes & 3,009 & 3,86 & 0,851 \\
\hline I16 & Social safety and security & 3,066 & 3,62 & 0,554 \\
\hline I18 & Friendliness \& honesty of local residents & 3,191 & 3,61 & 0,419 \\
\hline I19 & Beaches & 3,260 & 4,01 & 0,750 \\
\hline I1 & Quadrant 3: Low importance - Low satisfaction & & & \\
\hline I3 & Traditional festivals & 2,251 & 3,07 & 0,819 \\
\hline I4 & FoREX, internet connections, health care, etc. & 2,345 & 3,29 & 0,945 \\
\hline Diversification and differentiation of the local and & 2,462 & 3,09 & 0,628 \\
\hline tourism products & $\begin{array}{l}\text { Professionalism and behaviour of the staff of tourism } \\
\text { service providers }\end{array}$ & 2,628 & 3,3 & 0,672 \\
\hline I8 & Historical and cultural sites & 2,677 & 2,95 & 0,273 \\
\hline & Craft villages & 2,719 & 3,12 & 0,401 \\
\hline I9 & Quadrant 4: Low important - High satisfaction & & & \\
\hline I10 & $\begin{array}{l}\text { The involvement and participation of local people to } \\
\text { tourism services }\end{array}$ & 2,862 & 3,17 & 0,308 \\
\hline I12 & Preservation - conservation of tourism sites & 3,006 & 3,19 & 0,184 \\
\hline I14 & Quality of transportation & 3,053 & 3,22 & 0,167 \\
\hline I15 & Local speciality & 3,057 & 3,19 & 0,133 \\
\hline I17 & Accessibilities to the Phu Quoc & 3,085 & 3,33 & 0,245 \\
\hline
\end{tabular}

Source: Own (2018) 


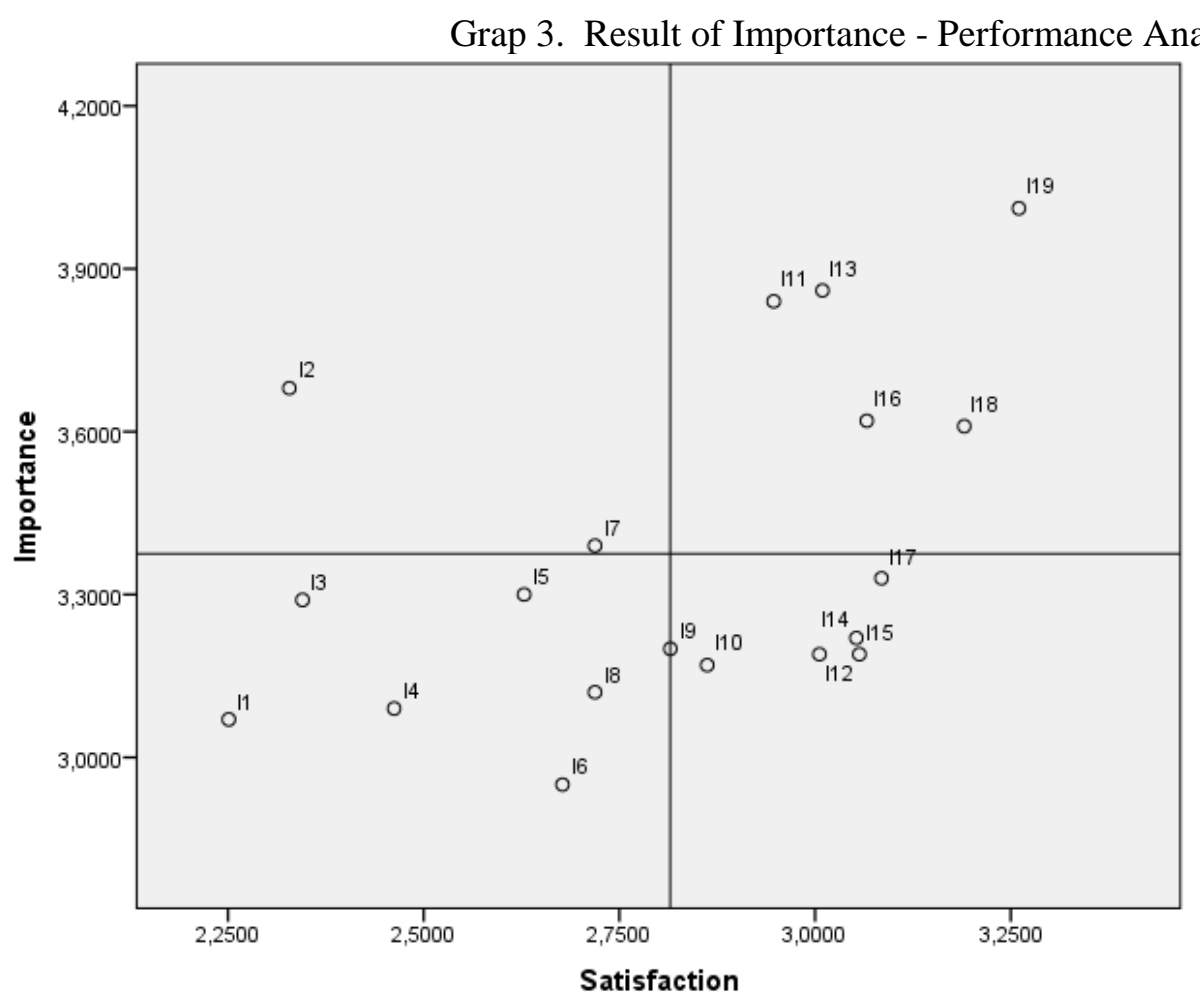

Source: Own (2018)

\section{According to the above IPA result:}

Quadrant 1 (High importance and low satisfaction): There are 2 attributes of reasonable price and quality of accommodation falling in the group of high importance but low satisfaction.

Quadrant 2 (High importance and high satisfaction): Attributes of Air and environment conditions; Natural sightseeing/landscapes; Social safety and security; Friendliness \& honesty of local residents; and Beaches have gained the high importance and high satisfaction. Thus, these variables should be retained and promoted.

Quadrant 3 (Low importance and low satisfaction): The traditional festivals; Quality of extra-services as banking systems, FOREX, internet connections, health care, etc.; Diversification and differentiation of the local and tourism products; Professionalism and behavior of the staff of tourism service providers; Historical and cultural sites; and Craft villages are included. These attributes can be safely untouched at the moment to use the scared resources for other ones.

Quadrant 4 (Low importance and high satisfaction): Quality of gastronomy (foodstuff); The involvement and participation of local people to tourism services; Preservation - conservation of tourism sites; Quality of transportation; Local speciality; and Accessibilities to the Phu Quoc should be received less attention and resources and efforts to enhance this element needs to be considered carefully.

\section{4 . Strategies proposed for sustainable tourism development in Phu Quoc}


As a result of SWOT analysis, IPA analysis, some of the strategies are suggested to fit those objectives for tourism sustainable development of Phu Quoc as following. Especially, these strategies are consulted with 12 experts by using indept interviews for thier resonabilities and validities.

\section{Strategy 1: Ecologically and environmentally sustainable development}

Phu Quoc's environmental quality is severely degraded by many different causes. Therefore, strategies of tourism development on the ecologically and environmentally sustainable development should be established with programs as Planning, establishing and developing collections of ecosystems; developing environmental- friendly tours; etc. Furthermore, in order to best protect the ecology and environment, in Phu Quoc, specific regulations such as rewards and punishments for environmental protection, heritage protection, etc. should also be issued and applied strictly to all island objects such as tourists, businesses, people, etc. In addition, the application of international standards and scientific research in the field should be concerned.

Concerning about this issue, Expert A, B and C who are serving in the tourism-related goverment agencies stated that:

Expert A: "Although the environmental issue is not the focus recently in Phu Quoc tourism development, it is considerable environmental issues arised when there are too many projects and too fast grwoing tourism sectors. We are afraid that we might loose control of the problem in hand soon."

Expert B: "We will fail at this problems (the environmentall issue) if missing the local residents' enthusisam and participations. The tourism companies' efforts to protect the environmental issue are not enough if local residents are not aware of the serious of the issue."

Expert C: "Although tourism companies in Phu Quoc island are willing to participate in ecolocial and environmental preservation, they lacks of the instructions from meta strategies supporting by local authorities. We are working on this issue and hope that it will be solved soon."

\section{Strategy 2: The strategy of product development and diversification}

The current tourists' satisfaction and the return rate are low because of the undifferentiated products, as a result, the strategies of product diversification should be paid attention. Many other kinds of tourism products are not exploited fully. For example, with the very beautiful beaches and favourable climate and weather, many other kinds of tourism products such as windsurfing, scuba diving, snorkelling, yachting, water skiing, etc. can be discovered and developments. In addition, man-made tourism products as craft village tourism, historical and cultural tourism, and festivals tourism, etc. are not evaluated highly and importantly by tourists.

Concerning about this issue, Expert D, E, F who are academic professors working on some tourism-related research projects in Phu Quoc argued that:

Expert D: "Tourists are satisfied with the natures and sight seeing in Phu Quoc island but they usually complains about the lack of tourism services during their stays at Phu Quoc. That's why they prefer to spend short holiday not the extended one in Phu Quoc."

Expert E: "We currently are currently collecting and analysing data on foreign tourists satisfaction about many tourism services attributes. We genrally found that foreigners are looking for more entertianmemts activities to fulfill their stays in Phu Quoc islands. It seems that only the beaches and local food can not keep them happy for a long-term." 
Expert F: "We are more interested in domestic tourists and found that they feel the value they received is not worth the money they are paying for. The difficulties in geography location make costs for basic needs in Phu Quoc is rather high comparing with other tourism regions."

\section{Strategy 3: The strategy of local marketing and promotion}

The current marketing and promotion of Phu Quoc tourism sector may not work well. Therefore, the strategy of local marketing and promotion is proposed through strategic or long-term marketing and promotional projects. To have fully completed strategy toward the sustainable tourism development, the related government authorities should get comments from the local community on tourism development plans or projects to understand their thoughts, comments and seek their agreement and high cooperation. The government authorities should be in leading to connect and coordinate all the sectors.

Concerning about this issue, Expert $\mathrm{A}$ and 2 managers $\mathrm{G}$ and $\mathrm{H}$ in tourism companies claimed that:

Expert A: "Although investments in tourism projects are pouring in Phu Quoc, each project has its own marketing strategy and they are not working together for developing an meta strategy for marketing and promoting Phu Quoc as a tourism destination as a whole. We need to get them cooperate with each other on this issues."

Expert G: "We are seeking supports from goverment to invest more on tourism activities, but we are usually prohibited by some other problems such as the objections from local residents."

Expert H: "The competitive picture is more intense. We sometime must cut prices in the short-term to compete with key competitors. We know that it is not the wise move because it affects hugely on the service quality and the images of Phu Quoc as a high-quality tourism destination in the long-term."

Strategy 4: The strategy of investment attraction to enhance the infrastructure

Phu Quoc tourism is currently in the development stage, as known, in the development process, it is required many resources and also attract huge investment. This growth if not properly control can create social and environmental risks in the long-term. The too-fast growth rate can make the painful and unnecessary sacrifices of the social and environmental aspects for serving the uncontrolled expanding of new tourism projects and investments. Therefore, the investment attraction to enhance and develop infrastructure is needed as the foundations first but it needed to be controlled to be aligned with sustainable development strategy for the tourism sector in Phu Quoc island.

Concerning about this issue, Expert $\mathrm{C}$ posited that:

Expert C: "As a government agency on tourism activities, we always seek for the balance between fast growths and sustainable development. It is not easy, especially when there are tradeoffs between short-term economic rewards and long-term developments. We need to stick to that principle."

\section{Strategy 5: The strategy of human resources enhancement and development}

As known, human resources play important roles in all organizations especially in the tourism management, and it is one of the most important determinants of tourism development. Completely, training or education programs should be provided and supported to the authorities' office, local residents, or businesses, especially for local tourism SMEs to enhance the tourism management skills, professional skills and develop their human resource. The training or education programs should concentrate on the improvement of the 
management skills, professional skill and competency, sustainable tourism awareness, and environment protection, etc.

Concerning about this issue, Expert D stated that:

Expert D: "It's a complex issue as it will take time and relates to many other aspects such as: standard living, social and cultural issues. For instances, in our research, we found that only $20 \%$ of high-quality employees of tourism business in Phu Quoc islands are the local one. This issue might create serious problems when most of the high-quality resides anytime soon."

\section{Conclusions}

As one of the fastest growing economic sectors, tourism has a great contribution to the development not only in the world but in Vietnam and Phu Quoc as well. As for Vietnam and Phu Quoc case, sustainable tourism development is the right direction to be pursued.

Phu Quoc is with potential and advantages for tourism development. In recent years, with the high efforts to exploit and promote these advantages, Phu Quoc tourism has gained some achievements, however, the development of tourism is not sustainable. The principles and calendar of sustainable tourism development have not fully complied, and social and environmental facets are not considered properly. As planned by the Vietnam and Kien Giang provincial governments, in the upcoming period, with the development orientation of the tourism to be the key driver not only in Phu Quoc but also in Kien Giang Province and Vietnam, it is required to be in a sustainable development direction for Phu Quoc tourism. In fact, the study of sustainable tourism development in Phu Quoc is of great importance for the development of Phu Quoc tourism in the coming years and the future.

As in its development, Phu Quoc tourism shows its unsustainability. Practically, the study is timely and accurate in the current conditions, as a result, the outcomes are certainly for Phu Quoc tourism. Furthermore, all the results are used as the scientific proofs and a firm basis to give concrete recommendations for the destination. And many findings of this study can be transferred to other destinations with a similar context. Above all, apart from concrete aforementioned recommendations, a general roadmap was delineated as a guide to implementing strategies to sustainable tourism development. This approach is not only for Phu Quoc but rather can be used for many other destinations on their way towards more sustainability. With respect to theoretical contribution, the contribution is useful for the future theoretical developments in the sustainable tourism development discipline and the research sheds lights on a number of theoretical issues as the reconfirmation of the stakeholders' involvement in the process of tourism development and sustainable tourism development, the tourism impacts on negative and positive sides to the socio-cultural, environmental, and economical. Specifically, the value of mixed method adaption is also reinforced to better understand all the perspectives of sustainable tourism development, meaning that a similar approach could be used in the future in other similar regions. More of that, the study can be used for teaching as a case study.

Additionally, the study limitation is on the sample because tourist questionnaire has been distributed in English only, sample members who do not speak English were not able to complete the survey in a manner that best reflections of their views. Online completion of the study was encouraged and therefore those without access to the Internet may have been hindered in completing the survey. To have the more accurate evaluation, more and more 
data is required. In general, the above-mentioned shortcomings and weakness can be settled by further studies. On the other hand, from the limitations of the study, many other studies should be drawn out. In term of the limitation of the sampling techniques, future studies can incorporate methodological changes that might provide responses to have more representative of the population to gain more accurate and deep findings for the study. Additionally, surveys could also be distributed in multiple languages to understand the thoughts and total satisfaction which is very useful for studies of sustainable tourism development. This study can also be expanded to include a greater focus on determining what factors for each specific stakeholder group are related to different levels of support for sustainable actions in tourism development. Furthermore, more work can be implemented to determine the level of support for tourism development within each cluster or exploited the level of impacting factors. By expanding the exploration to sustainable actions, which encompass environmental issues as well as socio-cultural and economic issues, different attitudes towards tourism might be identified.

\section{References}

1. Abalo, J., Varela, J. \& Manzano, V. (2007). Importance values for importanceperformance analysis: A formula for spreading out values derived from preference rankings. Journal of business research, 60(2), 115-121.

2. Aksu, A., Icigen, E.T., \& Ehtiyar, R. (2010). A comparison of tourist expectations and satisfaction: A case study from Antalya region of Turkey. Turizam, 14(2), 6677.

3. Batta, R. N. (2009). Green tourism certification manual. Tokyo: Asian Productivity Organization (APO). Retrieved from http://www.apo-tokyo.org/publications/wpcontent/uploads/sites/5/gp-18-gtcm.pdf

4. Bauman, Z. (2005). Liquid life. Polity Publisher.

5. Butler, R. W. (1993). Tourism an evolutionary perspective. In J. G. Nelson, R. Butler, \& G. Wall (Eds.). Tourism and sustainable development: monitoring, planning, managing (pp 26-43). Waterloo: Heritage Resources Centre. University of Waterloo.

6. Caribbean Tourism Organization (2008). Caribbean sustainable tourism policy framework. Retrieved from http://www.onecaribbean.org/content/files/CbbnSustainableTourismPolicyFramew ork.pdf

7. Charters, T. \& Saxon, E. (2007). Tourism and Mountains: A Practical Guide to Managing the Environmental and Social Impacts of Mountain Tours. United Nations. Retrieved from http://wedocs.unep.org/handle/20.500.11822/7687

8. Chen, X. (2013). The modified importance-performance analysis method and its application in tourist satisfaction research. Tourism tribune, 28(11), 59-66.

9. Choi, H.C., \& Sirakaya, E. (2006). Sustainability indicators for managing community tourism. Tourism management, 27(6), 1274-1289.

10. Chu, R.K.S. \& Choi, T. (2000). An importance-performance analysis of hotel selection factors in the Hong Kong hotel industry: a comparison of business and leisure travellers. Tourism management, 21(4), 363-377.

11. Conaghan, A., Hanrahan, J. \& Mcloughlin, E. (2015). The sustainable management 
of a tourism destination in Ireland: a focus on County Clare. Advances in hospitality and tourism research (AHTR) - An international journal of Akdeniz university tourism faculty, 30(1), 62-87.

12. Dola, K., \& Mijan, D. (2006). Public participation in planning for sustainable development: operation questions and issues. International journal on sustainable tropical design research and practice, 1(1), 1-8.

13. Dredge, D., \& Jamal, T. (2013). Mobilities on the Gold Coast, Australia: Implications for destination governance and sustainable tourism. Journal of sustainable tourism, 21(4), 557-579.

14. Elbe, J., Hallén, L., \& Axelsson, B. (2009). The destination-management organization and the integrative destination-marketing process. International journal of tourism research, 11(3), 283-296.

15. European Commission - EC (2004). Study on indicators of sustainable development at the local level. European Community. Available at https://ec.europa.eu/jrc/en/publication/eur-scientific-and-technical-researchreports/indicators-sustainable-development-local-level.

16. Farmaki, A., Altinay, L., Botterill, D., \& Hilke, S. (2015). Politics and sustainable tourism: the case of Cyprus. Tourism management 47, 178-190.

17. Figge, F., \& Hahn, T. (2006). Looking for sustainable value. Environmental finance, 7(8), 34-35.

18. Franch, M., Martini, U., Mich, L. \& Inverardi, N.P.L. (2002). E-tourism project research areas and second-year results. No. 79, Quaderni DISA. Department of Computer and Management Sciences, University of Trento, Italy.

19. Freeman, R.E. (1984). Strategic Management: A stakeholder approach. Boston: Pitman

20. Fuchs, M., \& Weiermair, K. (2003). New perspectives of satisfaction research in tourism destinations. Tourism review, 58(3), 6-14.

21. Goranczewski, B., \& Puciato, D. (2010). SWOT analysis in the formulation of tourism development strategies for destinations. Tourism, 20(2), 45-53.

22. Griffin, K., Flanagan, S. \& Fitzgerald, J. (2012). The challenge of implementing a sustainable tourism assessment tool in an urban environment. Paper presented at ATLAS annual conference 2012, Re-creating the Global City. London, UK.

23. Hall, C.M. (1996). Tourism and politics: policy, power, and place. Wiley Publisher.

24. Hens, L. (1998). Tourism and environment, Free University of Brussels, Belgium.

25. Higgins-Desbiolles, F. (2009). International Solidarity Movement: a case study in volunteer tourism for justice. Annals of leisure research, 12(3-4), 333-349.

26. Jamieson, W. \& Noble, A. (2000). A manual for sustainable tourism destination management. Canadian University Consortium - Urban Environmental Management Project. Retrieved from http://www.ucalgary.ca/ev/designresearch/projects/2000/cuc/tp/outreach/destinatio n\%20manual.pdf

27. Jamieson, W. (2006). Community destination management in developing economies. Psychology press.

28. Jurigová, Z., \& Lencsésová, Z. (2015). Monitoring system of sustainable development in cultural and mountain tourism destinations. Journal of Competitiveness. 
29. Kien Giang Statistical Office (2018). Annual report of Phu Quoc island district on the socio-economic situation 2018. Retrieved from http://cucthongkekg.gov.vn/news.php?id=1710

30. Kien Giang Statistical Office (2019). Annual report of Phu Quoc island district on the socio-economic situation $2018 . \quad$ Retrieved from http://cucthongkekg.gov.vn/news.php?id=1814

31. Kitcharoen, K. (2004). The importance-performance analysis of service quality in administrative departments of private universities in Thailand. ABAC journal, 24(3), 20-46.

32. Lai, I.K.W., \& Hitchcock, M. (2015). Importance-performance analysis in tourism: A framework for researchers. Tourism Management, 48, 242-267.

33. Liu, Z. (2010). Sustainable tourism development: A critique. Journal of sustainable tourism, 11(6), 459-475.

34. Lück, M., (2011). An importance-performance analysis of backpackers at Robinson Crusoe Island Resort, Fiji. ARA journal of tourism research, 3(1): 43-53.

35. Mashokhida, A., Khabibovich, A. A., Pálka, P., \& Shakhlo, R. (2018). The Competitiveness and Sustainable Economic Development of Tajikistan Regions. Journal of Competitiveness, 10(1), 73.

36. Matzler, K., Bailom, F., Hinterhuber, H.H., Renzl, B., \& Pichler, J. (2004). The asymmetric relationship between attribute-level performance and overall customer satisfaction: A reconsideration of the importance-performance analysis. Industrial Marketing Management, 33(4), 271-277.

37. McIntosh, R.W., Goeldner, C.R., \& Brent Ritchie, J.R. (1995). Tourism: Principles, practices, philosophies. New York: Wiley.

38. Mezei, K.A. (2009). Tourist destination management. Journal of tourism (Revista de Turism) 8, 52-58.

39. Oh, H. (2001). Revisiting importance-performance analysis. Tourism Management, 22(6), 617-627.

40. Otto, J.E. \& Ritchie, J.R. (1995). Exploring the quality of the service experience: A theoretical and empirical analysis. In T.A. Swartz, D.E. Bowen, and S.W. Brown, (Eds.). Advances in services marketing and management: Research and practice. Greenwich, CT: JAI Press.

41. Pforr, C. (2004). Policy-making for sustainable tourism. Sustainable tourism, 83$94 . \quad$ Retrieved from https://www.witpress.com/Secure/elibrary/papers/ST04/ST04007FU.pdf

42. Phu Quoc district (2017). Annual report of Phu Quoc island district on the socioeconomic situation $2017 . \quad$ Retrieved from http://phuquoc.gov.vn/Chiti\%E1\%BA\%BFttint\%E1\%BB\%A9c/tabid/99/ArticleID 12181/CateID/62/View/Detail/language/vi-VN/Default.aspx

43. Plachciak, A. (2009). Sustainable development-the way of building just society. Economics \& Sociology, 2(1), 105.

44. Pridham, G., (1996). Tourism policy in Mediterranean Europe: Towards sustainable development. University of Bristol (Centre for Mediterranean Studies): Bristol.

45. Rio, D., \& Nunes, L.M. (2012). Monitoring and evaluation tool for tourism destinations. Tourism management perspectives 4, 64-66.

46. Ritchie, J.R.B. (1988). Consensus policy formulation in Tourism: Measuring 
resident views via survey research, Tourism management, 9(3), 199-212.

47. Robinson, M., Kleffner, A., \& Bertels, S. (2011). Signaling sustainability leadership: Empirical evidence of the value of DJSI membership. Journal of business ethics, 101(3), 493-505.

48. Saner, R., Yiu, L. \& Filadoro, M. (2015). Tourism development in least developed countries: challenges and opportunities. In Handbook of research on global hospitality and tourism management (pp. 234-261). IGI Global Publication. Hershey:

Penn. http://www.csend.org/images/articles/files/Tourism_Dev_in_LDCs.pdf

49. Scheyvens R. (2011). The challenge of sustainable tourism development in the Maldives: Understanding the social and political dimensions of sustainability. Asia Pacific viewpoint, 52(2), 148-164.

50. Selin, S., \& Chavez. D. (1995). Developing a collaborative model for environmental planning and management. Environmental management, 19(2), 189-195.

51. Sever, I. (2015). Importance-performance analysis: A valid management tool?. Tourism management, 48, 43-53

52. Sheehan, L., Ritchie, J. R.B., \& Hudson S. (2007). The destination promotion triad: understanding asymmetric stakeholder interdependencies among the city, hotels and DMO. Journal of travel research, 46(1), 64-74.

53. Silva, F. \& Fernandes, O. (2010). Using importance-performance analysis in evaluating of higher education: A case study. Paper presented at ICEMT 2010 International Conference on Education and Management Technology. IEEE. (Pp. 121-123). Cairo, Egypt.

54. Simpson, F., \& Roberts, L. (2000). Help or hindrance? Sustainable approaches to tourism consultancy in Central and Eastern Europe. Journal of sustainable tourism, $8(6), 491-509$.

55. The Government of Vietnam (The government). (2013). Decision No. 201/QD-TTg (22 January 2013) issuing "Strategy on Viet Nam's tourism development until 2020, vision to 2030.

56. United Nations Environment Programme - UNEP \& World Tourism Organization - UNWTO (2005). Making tourism more sustainable: a guide for policy makers. United Nations. Retrieved from http://www.unep.fr/shared/publications/pdf/dtix0592xpa-tourismpolicyen.pdf.

57. United Nations Environment Programme - UNEP (United Nations Environment Programme). (2003). Tourism and local agenda 21: The role of local authorities in sustainable tourism (1st ed.). United Nations Publication. Retrieved from http://www.unep.fr/shared/publications/pdf/3207-TourismAgenda.pdf

58. Veal, A.J. (2002). Leisure and tourism policy and planning. Wallingford, UK: CABI

59. Wade, D., \& Eagles, P. (2003). The use of importance-performance analysis and market segmentation for tourism management in parks and protected areas: An application to Tanzania's National Parks. Journal of ecotourism, 2(3), 196-212.

60. Weber, K. (2000). Meeting planners' perceptions of hotel-chain practices and benefits: An importance-performance analysis. The Cornell hotel and restaurant administration quarterly, 41(4), 32-38.

61. Welford, R., \& Ytterhus, B. (2004). Sustainable development and tourism destination management: A case study of the Lillehammer region, Norway. International journal of sustainable development and world ecology, 11(4), 410- 
422.

62. Wheeler, B. (1993). Sustaining the ego. Journal of sustainable tourism, 1(2), 121129.

63. Wollnik, C. (2011). Sustainable destination management in Timor-Leste, (Doctoral thesis). Retrieved from https://www.tourismwatch.de/files/diplomarbeit_christian_wollnik_2011_timor-leste.pdf

64. World Tourism Organisation - UNWTO (2001). The concept of sustainable tourism. Retrieved from World Tourism Organization http://sdt.unwto.org/content/about-us$\underline{5}$

65. World Tourism Organisation - UNWTO (2007). A practical guide to destination management. Madrid: Spain.

66. World Tourism Organisation - UNWTO (2013). Sustainable tourism for development guidebook (2013). World Tourism Organization. Retrieved from https://www.e-unwto.org/doi/pdf/10.18111/9789284415496

67. World Tourism Organisation - UNWTO (2015). Destination management and quality programme. Retrieved from World Tourism Organization http://destination.unwto.org/event/4th-global-summit-city-tourism

68. World Tourism Organisation - UNWTO (WTO, 2005). UNWTO Tourism Highlights, 2005 Edition. World Tourism Organization. Retrieved from https://www.e-unwto.org/doi/pdf/10.18111/9789284411900

69. Yasenok S.N., \& Stenyushkina S.G (2016). The contents of strategic management in the tourism industry (on the example of Belgorod region). Technologies of business and service, 2(2), 28-33.

70. Ziegler, J., Dearden, P., \& Rollins, R. (2012). But are tourists satisfied? ImportancePerformance Analysis of the Whale Shark Tourism Industry on Isla Holbox, Mexico. Tourism Management, 33(3), 692-701.

71. Zielińska, A. (2010). Sustainable Development as a Determinant of Functioning the Valuable Natural Areas. Ukraine and Poland: selected social-economic and environmental issues, 161-171.

\section{Brief description of Author/Authors:}

\section{Vu Minh Hieu, Ph.D.}

After completing Ph.D program at the Mendel University in Brno, Czech Republic, Vu Minh Hieu is currently employing as a full-time lecturer in Faculty of Commerce and Business Administration at Van Lang University in Vietnam. His research focus is in the field of management, strategic management and human resources management. His contact is vuminhhieu@vanlanguni.edu.vn

\section{Ngo Minh Vu, Ph.D.}

Ngo Minh Vu has successfully completed the Ph.D program at Tomas Bata University in Zlin, Czech Republic. Currently, he works as a full-time lecturer in Faculty of Commerce and Business Administration at Van Lang University in Vietnam. He has participated in numerous research in the field of management and financial management. His research interests are management and financial management. His contact is ngominhvu@vanlanguni.edu.vn 